Western University

Scholarship@Western

Department of Economics Research Reports

Economics Working Papers Archive

1984

\title{
The Effects of Religion and Denomination on Earnings and the Returns to Human Capital
}

Nigel Tomes

Follow this and additional works at: https://ir.lib.uwo.ca/economicsresrpt

Part of the Economics Commons

Citation of this paper:

Tomes, Nigel. "The Effects of Religion and Denomination on Earnings and the Returns to Human Capital." Department of Economics Research Reports, 8411. London, ON: Department of Economics, University of Western Ontario (1984). 
ISSN : $\quad 0318-725 \mathrm{X}$

ISBN : $0-7714-0554-5$

RESEARCH REPORT 8411

THE EFFECTS OF RELIGION AND DENOMINATION

ON EARNINGS AND THE RETURNS TO

HUMAN CAPTTAL

Nigel Tomes

Department of Economics

University of Western Ontario

and

Economics Research Center/NORC

June 1984

* Monica van Huystee provided excellent research assistance. Two referees and the associate editor, Glen G. Cain, supplied constructive comments. The usual caveat applies.

${ }^{* *}$ forthcoming in Journal of Human Resources, Summer 1984. 


\begin{abstract}
AB STRACT
The effects of religious and denominational background on earnings and the returns to human capital are examined. When religious differences are constrained to be additive, apart from a Jewish differential, there is virtually no evidence that religious or denominational background affects earnings. This contrasts sharply with Greeley's claims of a sizeable Catholic advantage. In separate earnings regressions we find that the marginal returns to Catholics from college education exceed those to similar Protestants. This offsets the disadvantages of lower precollege returns. Earnings differences between Protestant denominations appear to reflect the sorting of Protestants into denominations according to schooling and income.
\end{abstract}




\section{INTRODUCTION}

During the last few decades economists have devoted considerable attention to black-white differences in earnings and the returns to human capital. More recently, attention has broadened to encompass other minority groups: Hispanics (Carliner [2], Long [13], Reimers [15], McManus et al [14]), Asian Americans (Chiswick [6]), and various immigrant groups (Chiswick [4], [5], Carliner [3], Borjas [1]). Earnings differences between religious groups have received less attention. One reason for this neglect is a data problem: surveys commissioned by the U.S. government do not ask questions on religion, so that researchers must resort to privately collected data sets. Barry Chiswick [7] overcame this problem by employing an innovative technique to identify Jews in the U.S. Census and found that compared to non-Jews, Jewish men have $16 \%$ higher earnings (other things the same) and a $20 \%$ higher rate of return to schooling $(0.080$ vs. 0.068). Similar Jewish-nonJewish differentials are reported by Tomes [18] for Canada.

A number of sociologists have examined income differences between other religious groups. The ranking of Catholics and Protestants has been controversial. Gockel [10] and Greeley [11] conclude that Catholics earn more than similar Protestants. Greeley, in particular, has argued forcefully that Catholics are members of the economic elite of America in terms of income. In contrast Featherman [9] and Roof [16] find no significant difference. However these studies have not been conducted within the 'human capital' framework. The dependent variable is typically 
family income rather than the log of earnings. Moreover in most of these studies, the effect of religion is additive with no interactions which would permit the rate of return to education to differ across religious groups.

Among economists, Taubman's study of the NBER-TH sample is exceptional in its inclusion of religious variables. He concludes that 'one of the major determinants of earnings was religion' (Taubman [17], p. 101). Holding constant education, ability and an extensive list of personal attributes and dimensions of family background, Taubman found that Protestants received 3-9\% less than Catholics (p. 40). Moreover, the growth rate of earnings of Catholics (over a 15 year period) exceeded that of Protestants by 5\% (pp. 130-133). ${ }^{2}$ The latter result is suggestive of higher rates of return for Catholics. However Taubman did not directly test if the returns to education and experience differed across religious groups. In addition it should be noted that the NBER-TH sample is not representative, so the se findings may not generalize to the U.S. population as a whole. In contrast, using Canadian census data, Tomes [18] found that the returns to Protestants from schooling, experience and possession of a university degree exceed those of comparable Catholics. Given the limited number of studies of the effects of religion and denomination on earnings and the rate of return to human capital, and the diversity of conclusions, further research appears justified. The present paper reports further empirical results for U.S. males using data from the NORC General Social Survey.

There is a further justification for the present paper. Previous studies have used current religious affiliation. Given a moderate degree of religious mobility this imperfectly measures religious background. A skeptical social scientist may attach no more causal significance to 
previously reported religious earnings differences, than to the finding that a dummy variable for membership in the Rotary Club or an exclusive golf club entered significantly in an income or earnings regression. Current religious affiliation may simply reflect a consumption choice. The present paper employs the religion in which an individual was raised--a measure which is clearly preferable in terms of endogeneity. Moreover, for purposes of comparison we examine how the results would be affected by the use of current religious affiliation. Section II describes the data and the variables employed in the empirical analysis. Section III presents empirical results and the final section contains a brief summary and conclusions.

\section{DATA AND SPECIFICATION}

The present investigation is based on the cumulative NORC General Social Surveys 1973-80 (Davis et al [8]). These data contain information on earnings, education, urban/rural and regional location. In addition, information was obtained on both current religious/denominational preference and the religion/denomination in which the individual was raised. Moreover, various dimensions of family background are available (parents' family income and education, father's occupation and place of birth, ethnic background, etc.) so that these can be controlled while analyzing the effects of education on (the log of) earnings. Table 1 describes the variables in more detail and mean values are reported in the appendix. The sample investigated consists of non-Hispanic white males age 25-64 with non-zero earnings. ${ }^{3}$ The estimation equation is quite conventional: the $10 \mathrm{~g}$ of earnings is regressed on education, experience and its square, personal characteristics 
TABLE 1 VARIABLE DEFINITIONS

LNEARN

Natural log of annual earnings from occupation, divided by the Consumer Price Index.

Persona1 Characteristics:

EDUCHS

EDUCCOL

EXPR

EXPRSQ

SELF *

UNION ${ }^{*}$

NOTMAR *

URBAN/RURAL LOCATION *

REGIONAL LOCATION ${ }^{*}$ :
Completed grades of schooling up to high school graduation (s 12)

Years of schooling beyond high school

Experience $=($ age - EDUC -6$)$

Experience squared

Self employed

Union member

Not married (never married, separated, divorced or widowed)

METRO (Central city or suburb of 12 largest SMSA's): Reference group: Central city or suburb of remaining 100 largest SMSA's; TOWN: Counties having towns of 10,000 or more; RURAL: Counties having no towns of 10,000 or more

Reference group: NE: New England States or Mid-Atlantic States; MIDWEST: East North Central or West North Central States; SOUTH: South Atlantic, West South Central or East South Central; WEST: Mountain States or Pacific States

Family Background:

RELIGION $^{*}$
LNRFAMINC
MOTHED
FRED
FATOCC
FBF $^{*}$
ETHNIC BACKGROUND ${ }^{*}$ :

(In what religion were you raised?) PROT: Protestant; CATH: Catholic; JEW: Jewish; NONE: none; OTHER: other Natural $\log$ of Relative Family Income of respondent's family at age 16 .

Highest grade of schooling completed by mother Highest grade of schooling completed by father

Hodge-Siegal-Rossi Occupational Prestige Score of father's occupation

Father born outside the U.S.

Reference Group: British Isles (England, Wales, Scotland or Ireland); WCEUR: West Central Europe (Austria, France, Germany, The Netherlands, Belgium, Switzerland); ECEUR:

East Central Europe (Czechoslovakia, Hungary, Poland, Yugoslavia, Lithuania); SEUR: Southern Europe (Greece, Italy); RUSSIA (USSR); SCAN: Scandinavia; NAMER: North America (America, Canada); OTHER (other)

Notes: * denotes dummy variable; 1 if criterion satisfied, 0 otherwise.

t categories far above average/above average/average/below average/far below average coded into relative income using the relationship between actual family income and perception of family income relative to the average estimated for the sample of respondents $(216 \%, 170 \%, 100 \%, 62 \%$ and $52 \%$ respectively). 
(union member, self-employed, not currently married), location (urban/rural and region) and family background. ${ }^{4}$ The education variable is entered as a linear spline function which allows the coefficient on years of college education (EDUCCOL) to differ from that on years of schooling up to high school graduation (EDUCHS).

In the present study we use the religion in which an individual was raised as one dimension of the goals, skills, connections and culture acquired as a result of belonging to a particular family. Religious upbringing may influence adult earnings via the labor market returns to religious instruction (e.g. admonitions regarding honesty, hard work and status attainment), access to different qualities of school (e.g. parochial vs. public), influencing occupational choice, discrimination based on religious background and other channels.

Previous studies have employed the respondent's current religious preference. In the presence of religious mobility this variable imperfectly measures religious background and may reflect the endogenous outcome of individual choice. Table 2 displays a significant amount of religious mobility. Based on the five-way classification in Table 2, $17.5 \%$ of individuals would be misclassified if current religious preference were used to measure religious upbringing. The major source of this misclassification is mobility into and out of the no religion category. Since religious mobility appears to be sizeable it is difficult to give a causal interpretation to regressions of earnings or income on current religious preference.

Our empirical study employs religious background to measure this dimension of family background. For purposes of comparison with previous studies we also report how our results would be affected by the use of current religious preference. 
TABLE 2 RELIGIOUS MOBILITY

RELIGION RAISED IN

\begin{tabular}{lccccc} 
CURRENT RELIGIONS & PROTESTANT & CATHOLIC & JEWISH & OTHER & NONE \\
\hline PREFERENCE & $85.8 \%$ & $8.2 \%$ & $1.5 \%$ & $3.3 \%$ & $52.7 \%$ \\
PROTESTANT & $3.8 \%$ & $80.5 \%$ & $2.9 \%$ & $13.3 \%$ & $4.3 \%$ \\
CATHOLIC & $0.1 \%$ & $0.3 \%$ & $80.9 \%$ & $0.0 \%$ & $0.0 \%$ \\
JEWISH & $0.7 \%$ & $0.6 \%$ & $1.5 \%$ & $76.7 \%$ & $3.2 \%$ \\
OTHER & $9.6 \%$ & $10.5 \%$ & $13.2 \%$ & $6.7 \%$ & $39.8 \%$ \\
NONE & -100.1 & 100.0 & 100.0 & 100.0 \\
& 10.0 & 100.1 & $(68)$ & $(30)$ & $(93)$
\end{tabular}

Notes: 1. Table shows current religious preference for individuals of each religious background.

2. Sample: White U.S. males age 25-64 with positive earnings. 
III. EMPIRICAI RESULTS

\section{A. Religion and the Returns to Human Capital}

Initial 'benchmark regressions' were estimated in which all religious groups were pooled and dummy variables for religious background were introduced. First, in order to analyze the 'total effect' of religion on earnings, the education, experience variables and personal characteristics (UNION, SELF and NOTMAR) were omitted. Log earnings was then regressed on family background, age and its square, location dummies and the religious background dummies.

Table 3, line 1 , reports the religion coefficients. Only the Jewish variable is significant, indicating that holding age, family background and location constant, Jews earn 35.9\% $(t=3.0)$ more than the Protestant reference group. However, when education and personal characteristics are introduced (line 2), none of the religious background variables are significant. 5 The sizeable earnings advantage of Jews (in line 1) appears mainly attributable to their higher levels of schooling--the 'net' (direct) effect is considerably smaller.

For purposes of comparison, lines 3 and 4 of Table 3 report equivalent regressions using current religious affiliation rather than religious background. The major difference is the Jewish-Protestant differential: $58.7 \%(t=4.2)$ in line 3 and $32.2 \%(t=2.4)$ in line 4. These results suggest that individuals who quit the Jewish religion are a non-random sample of individuals from a Jewish background.

The major conclusion to be drawn from Table 3 is that, holding school constant and constraining all coefficients to be equal across religious groups, except for the intercept, we find virtually no evidence of earnings differences 
TABLE 3 BENCHMARK EARNINGS REGRESSIONS

Religious Variables
Controls
CATH JEW NONE/OTHER
A. Religious Background
1. $\quad-0.0183 \quad 0.3065 \quad 0.1189$
$[0.468] \quad[3.011] \quad[1.573]$
family background, age and its square, location
2. -0.0503
[1.221]
0.0894
$[0.793]$
0.0585
$[0.790]$
family background, experience and its square, location, education, union, self-employment and marital status

B. Current Religious Preference

$\begin{array}{rrrr}\text { 3. } \begin{array}{rrr}0.0179 \\ {[0.439]}\end{array} & \begin{array}{r}0.4617 \\ {[4.209]}\end{array} & \begin{array}{c}0.0105 \\ {[0.2061]}\end{array} & \text { same as line } 1 \\ \text { 4. } & -0.0091 & 0.2794 & -0.0120 \\ {[0.218]} & {[2.384]} & {[0.242]} & \text { same as Iine } 2\end{array}$

Notes: 1. Dependent Variable is natural log of earnings.

2. Absolute value of $t$ statistic reported in parentheses beneath coefficients.

3. Regressions also included dummy variables for missing information on parents' education.

4. The reference group is Protestants. 
across major religious groups, except for the Jewish-Protestant differential just noted: The notable lack of any Catholic-Protestant differential is in marked contrast with the claims of Greeley [11], [12]. We turn now to examine whether the payoffs to earnings-generating characteristics differ across religious groups--that is, differences in the coefficients of the "human capital" earnings equation.

Table 4 (colums (1)-(4)) report separate earnings regressions for the four major religious groups according to religious background. Marked differences emerge. Chow tests indicate that the estimated coefficients differ between all groups except for the Jewish and None/Other groups which do not differ significantly. ${ }^{6}$ Column (5) therefore combines these latter two groups. 7

The estimated returns to schooling vary according to religious upbringing. The returns to college education for Catholics are significantly higher than those for Protestants (12.11\% versus $8.46 \%$ ) at the $7.5 \%$ level $(t=1.779)$. The returns to schooling up to grade 12 do not differ significantly between these two groups, although the point estimate for Catholics is considerably smaller than for Protestants. Since the mean level of schooling for both Protestants and Catholics exceeds twelve years, this implies that Catholics receive higher returns than Protestants from human capital investments at the margin in the form of college education. This higher marginal return eventually offsets the disadvantages of low returns to schooling prior to college. Evaluated at the mean characteristics for Protestants and Catholics, at six years of schooling earnings are approximately equal $(\$ 3,600)$. The higher returns to high school for Protestants create an earnings advantage which increases to $18 \%$ at twelve years of schooling $(\$ 5,600$ versus $\$ 4,750)$. The differential narrows to 
TABLE 4 EARNINGS REGRESSIONS FOR RELIGIOUS GROUPS

\begin{tabular}{|c|c|c|c|c|c|}
\hline & PROT & CATH & JEW & NONE/OTHER & JEW/NONE/OTH \\
\hline Column No. & (1) & (2) & (3) & (4) & $(5)$ \\
\hline EDUCHS & $\begin{array}{c}.07452 \\
(5.523)\end{array}$ & $\begin{array}{r}.0467 \\
(1.982)\end{array}$ & $\begin{array}{r}.2348 \\
(1.640)\end{array}$ & $\begin{array}{r}.1933 \\
(3.596)\end{array}$ & $\begin{array}{r}.1823 \\
(3.702)\end{array}$ \\
\hline BDUCCOL & $\begin{array}{r}.0846 \\
(8.901)\end{array}$ & $\begin{array}{r}.1211 \\
(8.267)\end{array}$ & $\begin{array}{r}.0813 \\
(1.526)\end{array}$ & $\begin{array}{r}.0777 \\
(2.031)\end{array}$ & $\begin{array}{c}.0898 \\
(3.151)\end{array}$ \\
\hline EXPR & $\begin{array}{r}.0798 \\
(19.323)\end{array}$ & $\begin{array}{r}.0870 \\
(13.200)\end{array}$ & $\begin{array}{r}.0555 \\
(1.794)\end{array}$ & $\begin{array}{r}.0690 \\
(4.761)\end{array}$ & $\begin{array}{r}.0741 \\
(5.886)\end{array}$ \\
\hline BXPRSQ & $\begin{array}{r}-.0013 \\
(17.928)\end{array}$ & $(11.15)$ & $\begin{array}{l}-.00055 \\
(1.009)\end{array}$ & $\begin{array}{l}-.00077 \\
(3.532)\end{array}$ & $\begin{array}{l}-.000909 \\
(4.762)\end{array}$ \\
\hline NOTMAR & $\begin{array}{c}-.2068 \\
(3.230)\end{array}$ & $\begin{array}{l}-.0565 \\
(.5189)\end{array}$ & $\begin{array}{c}.1253 \\
(.2958)\end{array}$ & $\begin{array}{c}.0917 \\
(.3841)\end{array}$ & $\begin{array}{c}.0867 \\
(.4260)\end{array}$ \\
\hline UNION & $\begin{array}{r}.2248 \\
(5.089)\end{array}$ & $\begin{array}{c}.2693 \\
(4.240)\end{array}$ & $\begin{array}{l}.2369 \\
(.7455)\end{array}$ & $\begin{array}{r}.2368 \\
(1.557)\end{array}$ & $\begin{array}{r}.2423 \\
(1.559)\end{array}$ \\
\hline SELF & $\begin{array}{r}.1232 \\
(2.278)\end{array}$ & $\begin{array}{r}.1116 \\
(3.178)\end{array}$ & $\begin{array}{l}.2378 \\
(.8249)\end{array}$ & $\begin{array}{c}.1578 \\
(.7580)\end{array}$ & $\begin{array}{r}.2394 \\
(1.529)\end{array}$ \\
\hline METRO & $\begin{array}{r}.1521 \\
(2.198)\end{array}$ & $\begin{array}{c}-.1078 \\
(1.344)\end{array}$ & $\begin{array}{r}-.4828 \\
(1.522)\end{array}$ & $\begin{array}{r}.7355 \\
(2.960)\end{array}$ & $\begin{array}{c}.1264 \\
(.7202)\end{array}$ \\
\hline TOWN & $\begin{array}{c}.0175 \\
(.3600)\end{array}$ & $\begin{array}{l}-.0538 \\
(.7204)\end{array}$ & $\begin{array}{l}-.1074 \\
(.3154)\end{array}$ & $\begin{array}{l}.2572 \\
(1.304)\end{array}$ & $\begin{array}{r}.1788 \\
(1.113)\end{array}$ \\
\hline RURAL & $\begin{array}{c}-.0422 \\
(.7410)\end{array}$ & $\begin{array}{r}-.2727 \\
(2.599)\end{array}$ & $\begin{array}{l}-. .4531 \\
(.7796)\end{array}$ & $\begin{array}{r}.2629 \\
(1.057)\end{array}$ & $\begin{array}{c}.0723 \\
(.3181)\end{array}$ \\
\hline SIDWEST & $\begin{array}{l}-.0204 \\
(.3243)\end{array}$ & $\begin{array}{l}.0285 \\
(.3414)\end{array}$ & $\begin{array}{l}-1.375 \\
(2.433)\end{array}$ & $\begin{array}{l}-.1176 \\
(.4626)\end{array}$ & $\begin{array}{c}-.1776 \\
(.9444)\end{array}$ \\
\hline South & $\begin{array}{l}-.0578 \\
(.9353)\end{array}$ & $\begin{array}{r}-.3400 \\
(3.550)\end{array}$ & $\begin{array}{r}-.7159 \\
(1.926)\end{array}$ & $\begin{array}{r}-.3221 \\
(1.094)\end{array}$ & $\begin{array}{l}-.1949 \\
(.9812)\end{array}$ \\
\hline WIEST & $\begin{array}{r}-.1817 \\
(2.635)\end{array}$ & $\begin{array}{l}.0891 \\
(.9755)\end{array}$ & $\begin{array}{l}-.0224 \\
(.0670)\end{array}$ & $\begin{array}{c}-.5503 \\
(2.120)\end{array}$ & $\begin{array}{r}-.3500 \\
(2.023)\end{array}$ \\
\hline LNRFAMINC & $\begin{array}{r}-.1011 \\
(1.732)\end{array}$ & $\begin{array}{l}.0558 \\
(.6303)\end{array}$ & $\begin{array}{l}-.1137 \\
(.3517)\end{array}$ & $\begin{array}{r}.2654 \\
(1.259)\end{array}$ & $\begin{array}{c}.1597 \\
(.9457)\end{array}$ \\
\hline SOTHED & $\begin{array}{l}.0044 \\
(.5465)\end{array}$ & $\begin{array}{l}.0039 \\
(.3399)\end{array}$ & $\begin{array}{r}.0580 \\
(1.299)\end{array}$ & $\begin{array}{c}-.0386 \\
(1.325)\end{array}$ & $\begin{array}{l}.0049 \\
(.0467)\end{array}$ \\
\hline FRED & $\begin{array}{r}.0120 \\
(1.700)\end{array}$ & $\begin{array}{l}.00098 \\
(.9280)\end{array}$ & $\begin{array}{c}-.0498 \\
(1.282)\end{array}$ & $\begin{array}{c}.0239 \\
(.9452)\end{array}$ & $\begin{array}{l}-.00518 \\
(.2586)\end{array}$ \\
\hline FATOCC & $\begin{array}{r}-.0019 \\
(1.247)\end{array}$ & $\begin{array}{l}.00085 \\
(.3775)\end{array}$ & $\begin{array}{l}-.00519 \\
(.5695)\end{array}$ & $\begin{array}{l}-.00283 \\
(.4851)\end{array}$ & $\begin{array}{l}-.00221 \\
(.4560)\end{array}$ \\
\hline FBF & $\begin{array}{l}-.0152 \\
(.1400)\end{array}$ & $\begin{array}{l}-.03625 \\
(.4049)\end{array}$ & $\begin{array}{r}-.3560 \\
(1.233)\end{array}$ & $\begin{array}{r}-.3901 \\
(1.422)\end{array}$ & $\begin{array}{l}-.0987 \\
(.5378)\end{array}$ \\
\hline WCEUR & $\begin{array}{l}.0358 \\
(.8305)\end{array}$ & $\begin{array}{r}.1954 \\
(2.490)\end{array}$ & $\begin{array}{l}.2272 \\
(.5078)\end{array}$ & $\begin{array}{l}-.0952 \\
(.5104)\end{array}$ & $\begin{array}{l}.00797 \\
(.0465)\end{array}$ \\
\hline ECEUR & $\begin{array}{c}.2642 \\
(1.527)\end{array}$ & $\begin{array}{r}.1440 \\
(1.725)\end{array}$ & $\begin{array}{l}.0631 \\
(.1704)\end{array}$ & $\begin{array}{l}-.1640 \\
(.4536)\end{array}$ & $\begin{array}{l}-.0508 \\
(.2328)\end{array}$ \\
\hline SEUR & $\begin{array}{r}.2939 \\
(1.159)\end{array}$ & $\begin{array}{l}.0476 \\
(.5744)\end{array}$ & - & $\begin{array}{r}.5979 \\
(2.082)\end{array}$ & $\begin{array}{r}.5224 \\
(1.969)\end{array}$ \\
\hline RUSSIA & $\begin{array}{l}.3436 \\
(.9018)\end{array}$ & $\begin{array}{l}.3600 \\
(.8217)\end{array}$ & $\begin{array}{r}.3111 \\
(1.093)\end{array}$ & $\begin{array}{c}-.4623 \\
(1.267)\end{array}$ & $\begin{array}{c}.0927 \\
(.4645)\end{array}$ \\
\hline SCAN & $\begin{array}{l}-.0171 \\
(.2210)\end{array}$ & $\begin{array}{l}-.1649 \\
(.7625)\end{array}$ & - & $\begin{array}{r}-.7651 \\
(1.542)\end{array}$ & $\begin{array}{r}-.5582 \\
(1.090)\end{array}$ \\
\hline OTHER & $\begin{array}{r}.9453 \\
(2.092)\end{array}$ & $\begin{array}{r}-. .3562 \\
(1.024)\end{array}$ & $\begin{array}{l}-.5753 \\
(.7612)\end{array}$ & $\begin{array}{c}.2559 \\
(.6043)\end{array}$ & $\begin{array}{c}.1216 \\
(.3520)\end{array}$ \\
\hline CONSTANT & $\begin{array}{c}2.130 \\
(10.870)\end{array}$ & $\begin{array}{c}2.355 \\
(7.453)\end{array}$ & $\begin{array}{l}1.079 \\
(.6189)\end{array}$ & $\begin{array}{l}1.197 \\
(1.628)\end{array}$ & $\begin{array}{c}1.092 \\
(1.672)\end{array}$ \\
\hline JEW & & & & & $\begin{array}{r}.4052 \\
(2.148)\end{array}$ \\
\hline MEIROJEW & & & & & $\begin{array}{l}-1.098 \\
(3.560)\end{array}$ \\
\hline N & 1658 & 710 & 68 & 122 & 190 \\
\hline $\mathrm{R}^{2}$ & .28493 & .33434 & .5839 & .52304 & .45149 \\
\hline
\end{tabular}


Notes to Table 4

1. Absolute value of $t$ statistic reported in parentheses beneath each coefficient.

2. Regressions also included dummy variables for missing information on parent $s^{\prime}$ education, coefficients not reported.

3. METROJEW is an interaction term between METRO and JEW. 
zero at sixteen years of schoolding, and thereafter the earnings of Catholics exceed those of similar Protestants. The conclusion that the marginal returns from a college education for Catholics exceed those to similar Protestants contrasts with the results obtained by Tomes [18] for Canada where the returns to Protestants from schooling exceeded those of Catholics. However, it is consistent with the results of Taubman for the U.S. The second difference that emerges from Table 4 is that the returns to schooling up to high school graduation (EDUCHS) for the Jewish and None/Other groups are sizeable and significantly exceed those of Protestants and Catholics--18.23\% for non-Catholic/non-Protestants in column (5) versus $7.45 \%$ for Protestants and $4.67 \%$ for Catholics, with $t$ statistics associated with these differences of 2.1 and 2.4 , respectively. The substantial returns to schooling for Jews (colum (3)) offer additional support for the conclusions of Chiswick [7] and Tomes [18]. However, given the small number of Jews in the present sample $(n=68)$ not much confidence can be placed in the point estimate of the returns to schooling for Jews (column (3)).

The interested reader is invited to examine the effects of other independent variables and differences across religious groups reported in Table 4.

Before proceeding it is worth examining how the results would be affected by the use of current religious preference rather than religious background. First, an additional variable was introduced into equations (1) -(4) indicating individuals who no longer expressed the same religious 
preference as that in which they were raised. This variable was statistically significant for both Catholics and Jews, but not for the other groups. The estimated coefficients imply that ex-Catholics earn $14 \%$ less than retentive Catholics $(t=2.1)$ and ex-Jews earn on $1 y 36 \%$ of the amount earned by retentive Jews $(t=3.1)$. The last result is too large to be believed and is no doubt influenced by the small sample size--there are only 13 ex-Jews in the sample. Of course these results are open to a variety of interpretations. They do suggest, however, that religiously mobile Catholics and Jews are a non-random sample of people raised in these religious backgrounds.

Second, the earnings equation was re-estimated on the basis of current religious preference. ${ }^{8}$ The major differences were that for the Jewish and None/Other groups the estimated returns to pre-college education declined and the returns to post-high school education increased. More importantly, the estimated returns to secondary education for Catholics equalled that for Protestants. Since the remaining coefficients do not change dramatically this eliminates the Catholic earnings disadvantage associated with low returns to high school reported in Table 4 and generates an increasing earnings advantage to college-educated Catholics relative to other Protestant counterparts. Thus, if current religious affiliation is used rather than religious background, the results are more favorable for Catholics. 


\section{B. Denomination and the Returns to Human Capital}

The foregoing analysis treats Protestants as a single group and ignores within-group denominational heterogeneity. At this point we shall examine whether there are denominational differences, particularly with respect to the returns to human capital variables. Again our measure of denomination is that in which the individual was raised--a dimension of family background-rather than current denominational preference. In $28.9 \%$ of the cases analyzed in our sample these two measures differ, reflecting a substantial amount of intergenerational denominational mobility.

Again a 'benchmark' regression was estimated which pooled all

Protestant denominations and held family background, age, and location constant, while permitting the intercepts to differ across denominations. Relative to the largest denomination--the Baptist reference group--only individuals who were raised Protestant with no denominational affiliation

had significantly different earnings--20\% less than Baptists $(t=2.01) .9$ Aside from this numerically small group--3.4\% of Protestants $(n=56)--n o$ significant differences in earnings emerge. This lack of denominational differences in earnings contrasts with Greeley's conclusion that in terms of family income members of some denominations (e.g., Episcopalians and Presbyterians) do significantly better than others (e.g. Methodists) (Greeley [12]).

Greeley, however, uses current denominational affiliation. 10 Re-estimating our 'benchmark regressions' on this basis generates results quite different from those reported above. Controlling for family background, location and age, Episcopalians earn $22 \%(t=1.78)$, Methodists $18.5 \%$ $(t=2.75)$, and Presbyterians 18.4\% $(t=2.05)$ more than the Baptist 
reference group. Moreover, the disadvantage to the no denomination group disappears. Once schooling, experience and personal characteristics are included only the Methodist coefficient (11.5\%) retains significance at the $10 \%$ level $(t=1.82)$. These results suggest that the earnings advantage of certain denominational groups (e.g. Episcopalians and Presbyterians), identified according to current denominational affiliation simply reflects denominational sorting by schooling and income, Table 5 reports the estimated coefficients on human capital variables from separate regressions for each of the five major denominational groups. The application of Chow tests ${ }^{11}$ for the equality of all coefficients across pairs of regressions lead to the amalgamation of denominations into two groups: Lutherans, Episcopalians and Presbyterians on the one hand and Baptists, Methodists, no denomination and 'other denomination' on the other. ${ }^{12}$ Concentrating on the coefficients reported in columns (1)-(5) of Table 4, none of the differences in education coefficients are significant at the 5\% leve1. Two differences are significant at the 10\% leve1: Methodists differ from Presbyterians/Episcopalians in the effects of EDUCHS $(t=1.73)$ and from the Other/No denomination group in terms of EDUCCOL $(t=1.73)$. However, of the 20 pairwise comparisons possible, two would be expected to be significant as a random occurrence using the $10 \%$ criterion. When the denominations are amalgamated into two groups in columns $(6)-(7)$ none of the differences in schooling coefficients are significant. Hence we cannot reject the hypothesis that the returns to schooling are identical for all denominations using conventional levels of significance. 
TABLE 5: EARNINGS REGRESSIONS FOR PROTESTANT DENOMINATIONS

\begin{tabular}{|c|c|c|c|c|c|c|c|}
\hline & BAPTIST & METHOD & LUTHER & PRESB/EPISC & OTHER/NODEN & $\begin{array}{l}\text { BAPTIST } \\
\text { METHOD } \\
\text { OTHER/NODEN }\end{array}$ & $\begin{array}{l}\text { LUTHER } \\
\text { PRESB } \\
\text { EPISC }\end{array}$ \\
\hline Column No. & (1) & (2) & (3) & (4) & (5) & (6) & (7) \\
\hline EDUCHS & $\begin{array}{r}.0787 \\
(3.911)\end{array}$ & $\begin{array}{l}.0229 \\
(.7482)\end{array}$ & $\begin{array}{r}.0877 \\
(2.165)\end{array}$ & $\begin{array}{r}.1510 \\
(2.237)\end{array}$ & $\begin{array}{r}.0682 \\
(2.237)\end{array}$ & $\begin{array}{l}.0668 \\
(4.603)\end{array}$ & $\begin{array}{r}.0926 \\
(2.760)\end{array}$ \\
\hline EDUCCOL & $\begin{array}{l}.0922 \\
(4.434)\end{array}$ & $\begin{array}{r}.1011 \\
(4.948)\end{array}$ & $\begin{array}{r}.0811 \\
(3.023)\end{array}$ & $\begin{array}{r}.0951 \\
(3.414)\end{array}$ & $\begin{array}{r}.0713 \\
(3.270)\end{array}$ & $\begin{array}{c}.08687 \\
(7.278)\end{array}$ & $\begin{array}{r}.0922 \\
(4.998)\end{array}$ \\
\hline EXPR & $\begin{array}{r}.0820 \\
(10.172)\end{array}$ & $\begin{array}{r}.1028 \\
(12.352)\end{array}$ & $\begin{array}{r}.0681 \\
(6.980)\end{array}$ & $\begin{array}{r}.0677 \\
(5.031)\end{array}$ & $\begin{array}{r}.0847 \\
(8.696)\end{array}$ & $\begin{array}{r}.0904 \\
(18.436)\end{array}$ & $\begin{array}{r}.0672 \\
(8.853)\end{array}$ \\
\hline EXPRSQ & $\begin{array}{l}-.00133 \\
9.502)\end{array}$ & $\begin{array}{r}-.0018 \\
(11.0860)\end{array}$ & $\begin{array}{c}-.00091 \\
(5.775)\end{array}$ & $\begin{array}{c}-.00097 \\
(3.938)\end{array}$ & $\begin{array}{r}-.0015 \\
(8.669)\end{array}$ & $(1 \overline{7} .0044)$ & $\begin{array}{l}-.000907 \\
(6.999)\end{array}$ \\
\hline $\mathrm{N}$ & 464 & 389 & 242 & 205 & 355 & 1,208 & 447 \\
\hline
\end{tabular}

Notes: 1. All regressions incluđed the personal characteristics, location and family background variables indicated in Table 4.

2. Absolute value of $t$ statistics in parentheses. 
Differences in experience profiles are more substantial. The two experience terms for Methodists differ significantly at the $5 \%$ level from both Lutherans and Presbyterians/Episcopalians, implying that the $10 \mathrm{~g}$ earnings-experience profile of Methodists is initially steeper and more concave than that of the other two groups. Furthermore, the EXPRSQ coefficient for Luterans differs significantly at the $5 \%$ level from both Baptists and members of the no denomination/other denomination group. These differences carry over to columns (6) and (7) where both the EXPR and EXPRSQ coefficients are significantly different across equations $(t=2.56$ and 4.00 , respectively). Thus although the returns to schooling are quite similar for the major Protestant denominations we do find some evidence of differing experience profiles.

\section{CONCLUSIONS}

This paper has examined the effects of religion and denomination on earnings and the returns to human capital (schooling and experience). In contrast to previous studies our results are based on religious background, rather than current religious preference. In the presence of religious mobility, the latter is endogenous. Moreover, we present evidence that among Jews and Catholics, religiously mobile individuals are a non-random sample in terms of earnings.

When the effects of human capital variables, personal characteristics, location and family background on log earnings are constrained to be equal for all religious groups, we find virtually no evidence that religious or 
denominational background affects earnings. The lack of any significant Jewish differential appears attributable to the small number of Jews in the sample. Strikingly, there is no evidence of any significant Catholic-Protestant differential (see $\mathrm{Table} 3$ ). The absence of any Catholic-Protestant earnings differential contrasts sharply with Greeley's evidence of a sizeable and significant Catholic advantage in terms of family income (Greeley [11], [12]).

When religious background is permitted to interact with other earnings-generating characteristics, differences in payoffs emerge. There is some evidence that the marginal returns to Catholics from college education exceed those to similar Protestants. However, these higher returns simply offset the disadvantage of lower returns to Catholics from secondary education, so that after a few years of college Catholic and Protestant earnings converge. Overa11, Catholic-Protestant differences in payoffs appear minor.

The finding that the marginal returns to college received by Catholics exceed those to Protestants contrasts with Tomes' [18] results for Canada that rates of return are lower for Catholics than Protestants and implies that it would be inadvisable to generalize Canadian findings regarding religious differences to North America as a whole.

Looking at denominational differences among Protestants we find virtually no evidence of earnings differentials, when the effects of other characteristics are constrained to be equal. Again, this result contrasts with Greeley's finding that Episcopalians and Presbyterians have significantly higher incomes than the members of other Protestant 
denominations (Methodists and Baptists) (Greeley [12]). We obtain results similar to those of Greeley if we use current denomination rather than denominational background and do not control for schooling. This suggests that previously reported denominational income differentials simply reflect the sorting of Protestants into denominations according to schooling and income. Lastly, we conclude that rates of return to schooling do not differ significantly across denominational backgrounds, but some denominations exhibit different earnings-experience profiles. 


\section{Footnotes}

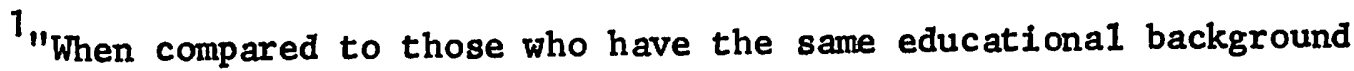
and occupational position, Catholics make $\$ 1,656$ a year more [than the national average], which makes them the most mobile group in American society, even more mobile than Jews." (Greeley [11], p. 27.] "Jews and the principal Catholic ethnic groups, in other words, have higher incomes nationally than do any Protestant denomination or ethnic group." (Greeley [11], p. 70.) "Catholics are significantly higher in income than the denominations which represent eighty-nine percent of American Protestants." (Greeley [12], p. 826.)

2Taubman's analysis also permits a comparison of Jews with other religious groups. Ceteris paribus Jews were found to earn 33-40\% more than Catholics and the growth rate of earnings of Jews exceeded that of Catholics by $21 \%$ (Taubman [17], pp. 40, 130-133).

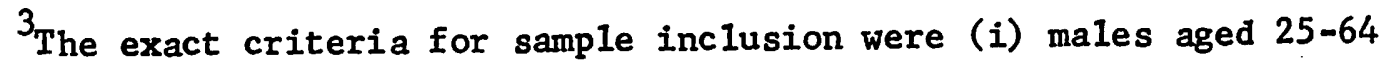
(inclusive); (ii) Race not black; (iii) Ethnic origin not Asian, Hispanic or Native Indian; (iv) With positive annual earnings (i.e., income from occupation); (v) no missing information on earnings, education or age.

4he sample did not contain information on weeks worked in the previous year. Hence variations in earnings reflect both variations in wage rates and labour supply (hours and weeks worked).

Since a significant fraction of cases (24.75\%) had missing information on parents' education, missing values were recoded at the mean of the non-missing values and dummy variables denoting the absence of information were included in the regressions. The coefficients on these variables are not reported in the tables presented below. 
${ }^{5}$ If Baptists, the Iargest Protestant denomination, are used as the reference group, rather than all Protestants, the coefficients indicate that Catholics earn $8.8 \%$ less than Baptists, other things equal $(t=1.70$, significant at the $9 \%$ level). The Jewish coefficient is $+4.8 \%(t=0.394)$.

$6_{\text {The }} \mathrm{F}$ statistics for the CHOW tests of equal coefficients are: Catholics vs. Protestants $F=1.863$; Protestants vs. None/Other $F=1.529$; Catholics vs. None/Other $F=1.911$; Jews vs. None/Other $F=1.250$. The critical value for significance at the $5 \%$ level is 1.52 .

${ }^{7}$ A comparison of individual coefficients between columns (3) and (4) indicates that the payoff to residence in the largest SMSA's differs significantly between the two regressions. Column (5) therefore introduces an interaction term between METRO and JEW (METROJEW) and also allows the constant terms to differ between the two groups (JEW).

8The schooling coefficients obtained when the sample is partitioned according to current religious preference are reported below:

\begin{tabular}{|c|c|c|c|c|}
\hline $\begin{array}{l}\text { Current } \\
\text { Religion: }\end{array}$ & $\begin{array}{l}\text { PROT } \\
\text { (I) }\end{array}$ & $\begin{array}{l}\text { CATH } \\
(2)\end{array}$ & $\begin{array}{l}\text { JEW } \\
\text { (3) }\end{array}$ & $\begin{array}{l}\text { NONE/OTHER } \\
\text { (4) }\end{array}$ \\
\hline EDUCHS & $\begin{array}{r}0.0701 \\
{[5.239]}\end{array}$ & $\begin{array}{r}0.0744 \\
{[2.829]}\end{array}$ & $\begin{array}{r}0.0048 \\
{[0.038]}\end{array}$ & $\begin{array}{r}0.0980 \\
{[2.474]}\end{array}$ \\
\hline EDUCCOL & $\begin{array}{r}0.0861 \\
{[8.159]}\end{array}$ & $\begin{array}{r}0.1225 \\
{[7.713]}\end{array}$ & $\begin{array}{r}0.1025 \\
{[2.211]}\end{array}$ & $\begin{array}{r}0.1073 \\
{[4.948]}\end{array}$ \\
\hline $\mathbf{N}$ & 1530 & 644 & 58 & 324 \\
\hline $\mathrm{R}^{2}$ & .2809 & .3254 & .6569 & .3913 \\
\hline
\end{tabular}

Notes: 1. See Table 4

2. All regressions included the same set of independent variables as in Table 4 . 
${ }^{9}$ When education, experience, UNION, SELF and NOTMAR are also included in the equation and age and its square dropped, a similar picture emerges. The 'no denomination' group earns $21 \%$ less than the Baptist reference group $(t=2.15)$. None of the other denominations are significantly different than Baptists.

$10_{\text {These differences may also reflect Greeley's use of family income }}$ rather than log earnings, or the reduced set of control variables in his regressions.

${ }^{11}$ The results of the Chow tests are tabulated below:

\begin{tabular}{|l|c|c|l|l|}
\cline { 2 - 5 } \multicolumn{1}{c|}{} & BAPTIST & MEIHODIST & LUTHERAN & EPISCOPAI/PRESB \\
\hline METHODIST & 1.234 & & & \\
\hline LUTHERAN & $1.625 *$ & $2.360 *$ & & \\
\hline EPISCOPAI/PRESB. & 1.457 & 1.372 & .855 & \\
\hline OTHER/NO DENOM. & 1.205 & 1.214 & $1.9123 *$ & $1.5066 * *$ \\
\hline
\end{tabular}

* significant at $5 \%$ level

** $10 \%$ level

The Chow test for combined Lutheran, Episcopalian and Presbyterian versus Baptist, Methodist, No denomination and 'other denomination' was $3.19^{*}$. 12 These groupings seem reasonable when compared to the patterns of intergenerational denominational mobility (current denominational preference versus denomination raised in). The Methodist denomination is the major destination of individuals raised Baptist who switch denominations (and vice versa). 'Other denominations' are the major destination of Protestants raised in 'no denomination' (and vice versa). The Lutheran denomination is the major destination of individuals raised Episcopalian. 


\section{References}

[1] Borjas, George. "The Earnings of Male Hispanic Immigrants in the United States." Industrial and Labor Relations Review 35, No. $2(1982): 343-353$.

[2] Carliner, Geoffrey. "Returns to Education for Blacks, Anglos, and Five Spanish Groups." Journal of Human Resources 11, No. 2 (1976): $172-84$

[3] . "Wages, Earnings and Hours of First, Second, and Third Generation American Males." Economic Inquiry 18, No. 1 $(1980): 87-102$.

[4] Chiswick, Barry R. "Sons of Immigrants: Are they at an Earnings Disadvantage?" American Economic Review (February 1977): 288-325.

[5] _. "The Effect of Americanization on the Earnings of Foreignborn Men." Journal of Political Economy 86, No. 5 (1978): 897-919.

[6] "An Analysis of the Earnings and Employment of AsianAmerican Men." Journal of Labor Economics 1, No. 2 (1983): 197-214. (a)

[7] _- "The Earnings and Human Capital of American Jews." Journal of Human Resources 18 , No. 3 (1983): 313-336.

[8] Davis, James A., Smith, Tom W., and Stephenson, Bruce C. General Social Survey Cumulative File, 1972-1980. ICPSR Edition (1981).

[9] Featherman, D. L. "The Socio-economic Achievement of White ReligioEthnic Subgroups: Social and Psychological Explanations." American Sociological Review 36 (1981): 207-222. 
[10] Gocke1, G. L. "Income and Religious Affiliation: A Regression Analysis." American Journal of Sociology 74 (1969): 632-646.

[11] Greeley, A. M. Ethnicity, Denomination and Inequality, Bever ley Hil1s: Sage Publications, 1976.

[12] Greeley, A. M. "Catholics and the Upper Middle Class." Social Forces 59, No. 3 (1981): 824-830.

[13] Long, James E. "Productivity, Employment Discrimination and the Relative Economic Status of Spanish Origin Males." Social Science Quarterly 58, No. 3 (1977): 357-373.

[14] McManus, Walter; Gould, William and Welch, Finis. "Earnings of Hispanic Men: The Role of Language Proficiency." Journal of Labor Economics 1, No. 2 (1983): $101-130$.

[15] Reimers, Cordelia W. "Sources of the Wage Gap Between Hispanic and Other White Americans." Mimeographed. Princeton, N.J.: Princeton University, 1980.

[16] Roof, W. C. "Unresolved Issues in the Study of Religion and the National Elite." Social Forces 59, No. 3 (1981): $831-836$.

[17] Taubman, P. Sources of Inequality in Earnings. North-Holland Publishing Co., Amsterdam, 1973.

[18] Tomes, N. "Religion and the Rate of Return on Human Capital: Evidence from Canada." Canadian Journal of Economics 16, No. 1 (1983): $122-138$. 
TABLE A: MEANS OF VARIABLES FOR RELIGIOUS GROUPS

Religious

Background:

LNEARN

EDUC

EDUCHS

EDUCCOL

EXPR

NOTMAR $(\%)$

UNION (\%)

SELF (\%)

METRO (\%)

TOWN (\%)

RURAL (\%)

MIDWEST (\%)

SOUTH (\%)

WEST (\%)

FATOCC

MOTHED

FRED

FBF (\%)

WCEUR (\%)

ECEUR $\cdot(\%)$

SEUR (\%)

SCAN (\%)

RUSSIA (\%)

OTHER (\%)

LNRFAMINC

N
PROT

$$
4.0434
$$

12.54

11.14

1.40

22.74

9.65

27.32

15.62

11.16

42.28

23.16

29.67

39.51

17.49

36.80

10.41

9.62

3.32

29.25

1.21

.54

7.06

.24

.18

$-.0548$

1658
CATH

JEW

4.4864

14.85

11.57

3.28

22.09

8.82

19.12

30.88

38.24

25.0

4.41

7.35

16.18

17.65

42.78

10.82

10.90

26.47

8.82

19.12

18.17

20.28

1.83

.42

.7

$-.0614$

710

38.24

2.94

.0594

68
NONE/OTHER

4.1169

12.75

11.02

1.73

21.85

11.48

24.49

19.67

16.39

38.52

17.21

33.61

21.31

27.87

32.98

9.86

9.55

16.39

27.87

5.74

11.48

2.46

5.74

4.92

$-.0869$

122
JEW/NONE/OTHER

4.2492

13.51

11.22

2.28

21.94

10.53

22.63

23.68

24.21

33.68

12.63

24.21

19.47

24.21

36.49

10.21

10.03

20.0

21.05

10.53

7.37

1.58
17.37

4.21

$-.0345$

190

Notes:- 1. EDUC is total years of schooling EDUC = EDUCHS + EDUCCOL. 